\title{
Correction to: CJSMTE: 20 Years Strong
}

D. McDougall $^{1}$ (D) S. Ferreyro-Mazieres ${ }^{1}$

Published online: 17 February 2021

(C) Ontario Institute for Studies in Education (OISE) 2021

\section{Correction to: Can. J. Sci. Math. Techn. Educ. https://doi.org/10.1007/s42330-020-00120-8}

Sofia Ferreyro-Mazieres was inadvertently omitted as an author of the article. The original article has been corrected.

Publisher's Note Springer Nature remains neutral with regard to jurisdictional claims in published maps and institutional affiliations.

The original article can be found online at https://doi.org/10.1007/s42330-020-00120-8.

D. McDougall

doug.mcdougall@utoronto.ca

1 Ontario Institute for Studies in Education, University of Toronto, 252 Bloor Street West, Toronto,

Ontario M5S 1V6, Canada 